\title{
Larval algae nutrition of Aedes communis (De Geer, 1776)
}

\section{Питание водорослями мичинок кровососущих комаров Aedes communis (De Geer, 1776)}

\author{
E.V. Panyukova, I.V. Novakovskaya, E.N. Patova \\ Е.В. Панюкова, И.В. Новаковская, Е.Н. Патова
}

Institute of Biology, Komi Science Centre, Ural Division RAS. E-mail: panjukova@ib.komisc.ru

Институт биологии Коми научного центра Уральского отделения РАН

KEY WORDS: Culicidae, Aedes communis, algae, nutrition, spruce forests.

КЛЮЧЕВЫЕ СЛОВА: Culicidae, Aedes communis, водоросли, питание, еловые леса.

ABSTRACT. The paper informs about larval nutrition of the Aedes communis (De Geer, 1776) (Diptera: Culicidae) blood-sucking mosquito in typical environments such as temporal water-bodies under spruce forests. Algae as a nutrition component for larvae of bloodsucking mosquitoes were analyzed for species composition. The work was done in dwarf shrub and green moss spruce forests in the outskirts of the Vylgort settlement (the Syktyvdinsky region, the Komi Republic). Using the complex approach, we obtained food samples with live algae from larval intestines and cultivated the samples in breeding grounds to specify algal species composition. Generally, 12 algal species from five orders were identified in larval intestines of $\grave{A}$. communis mosquitoes. They are Cyanobacteria/Cyanoprokaryota (Chroococcus sp., Anabaena sp.), Ochrophyta (Botrydiopsis eriensis J.W. Snow, Tribonema vulgare Pascher), Bacillariophyta (Pinnularia sp.), Chlorophyta (Bracteacoccus giganteus H.W. Bischoff et H.C. Bold, Chloroidium saccharophilum (W. Krüger) Darienko, Gustavs, Mudimu, Menendez, Schumann, Karsten, Friedl et Proschold, Microthamnion kuetzingianum Nägeli ex Kütz., Pseudococcomyxa simplex (Mainx) Fott, Schizochlamydella minutissima Broady, Stichococcus bacillaris Nägeli), and Streptophyta (Euastrum sp.). Several algal species from mosquito larval intestines are now maintained as live cultures in algal collection of the Institute of Biology (SYKOA).

Diatomic algae do not get destructed in A. communis intestines. Mosquitoes partly do not digest Ochrophyta and green algae which are situated in the middle of food bolus and often get out of the organism intact. The role of algae for nutrition of mosquito larvae is still understudied. Larvae feed on what they can. Like bottom particles, they possibly swallow diatomic algae to rub and mill food in intestines.
РЕЗЮМЕ. Приведены данные о питании личинок кровососущего комара Aedes communis (De Geer, 1776) (Diptera: Culicidae) в типичных средах обитания - временных водоемах еловых лесов. Выявлен видовой состав водорослей составляющих пищевой компонент личинок кровососущих комаров в ельнике кустарничково-зеленомошном в окр. пос. Выльгорт (Сыктывдинского р-на, Республики Коми). В результате применения комплексного подхода к изучению питания личинок комаров были получены пробы пищевых масс из кишечника личинок с живыми водорослями, которые удалось культивировать на питательных средах для уточнения видового состава. При вскрытии кишечника личинок комаров $A$. communis было обнаружено 12 видов водорослей из пяти отделов: Cyanobacteria/ Cyanoprokaryota (Chroococcus sp., Anabaena sp.), Ochrophyta (Botrydiopsis eriensis J.W. Snow, Tribonema vulgare Pascher), Bacillariophyta (Pinnularia sp.), Chlorophyta (Bracteacoccus giganteus H.W. Bischoff et H.C. Bold, Chloroidium saccharophilum (W. Krüger) Darienko, Gustavs, Mudimu, Menendez, Schumann, Karsten, Friedl et Proschold, Microthamnion kuetzingianum Nägeli ex Kütz., Pseudococcomyxa simplex (Mainx) Fott, Schizochlamydella minutissima Broady, Stichococcus bacillaris Nägeli) и Streptophyta (Euastrum sp.). Несколько видов водорослей из кишечников личинок комаров выделены в живые культуры и поддерживаются в коллекции водорослей Института биологии (SYKOA).

Экспериментально установлено, что в кишечнике A. communis не разрушаются диатомовые водоросли и частично не перевариваются охрофитовые и зеленые, находящиеся в центре пищевого комка. Роль в питании водорослями для личинок комаров до конца не выяснена. Предположительно, как и частички грунта, захватываемые личинками при безвыборочном питании, диатомовые водо-

How to cite this article: Panyukova E V., Novakovskaya I.V., Patova E.N. 2018. Larval algae nutrition of Aedes communis (De Geer, 1776) // Russian Entomol. J. Vol.27. No.4. P.443-449. doi: 10.15298/rusentj.27.4.13 
росли служат для перетирания и измельчения пищевого валика при механическом продвижении пищи по кишечнику. Охрофитовые и зеленые водоросли частично используются в питании, частично - выбрасываются наружу в неповрежденном виде.

\section{Introduction}

Blood-sucking mosquitoes (Diptera: Culicidae) are amphibious organisms as soon as imago inhabit ground and air but larvae and pupae develop in water. Larvae are food for numerous predatory insects and fish hatchlings. The majority of today's ecosystems count large numbers of dipterous organisms which play an important bio-cenotic role as organic matter destructors in different media. In water ecosystems, Diptera larvae are fish food and participate in self-purifying processes of water-bodies [Narchuk, 2003]. Insect-eating birds, dragonflies, robber flies, and bats feed on adult mosquitoes (imago) [Lyapunov, Panyukova, 2010]. In ground and water ecosystems, mosquitoes take a significant biomass part. Total annul yield of biomass at larval development stage makes $3 \mathrm{~g}$ from 1 $\mathrm{m}^{2}$ [Yurchenko, Belevich, 2016]. Larvae actively feed, grow, slough three times, increase in size and body weight, and then transform into pupae. Pupae of bloodsucking mosquitoes do not feed and grow. This stage lasts for several days. Pupae transform into imago. The metamorphosis processes need lots of energy and proceed only due to reserves of nutrients which were accumulated by larvae [Gutsevich et al., 1970; Tarasov, 1996].

Nutrition of mosquito larvae is being intensively studied for the purposes of mosquito cultivation to select food which will secure high fertility and viability of imago in culture. All mosquito (Culicidae) larvae are divided into predatory and plant-feeding organisms. Plant feeders, in turn, are divided into substrate scrapers, water or water surface film filter feeders. The process of feeding is nonselective and so larval intestines often contain small mineral particles. Size of particles larvae can swallow depends on size of larvae. Constitution of larval mouth relates to nutrition type. Head of scrapers is best developed in width not in length. Head index (ratio of head width maximum to length (without collar) exceeds 1 for scrapers and 1.5 for filter feeders [Yasyukevich, 2003]. After mouth, food passes into fore intestine with ducts of two salivary glands which produce digestive enzymes. The principle digestive enzyme of salivary glands is amylase which splits starch and glycogen. Then, food reaches mid-intestine where it gets split and absorbed with help of epithelium enzymes of mid-intestine. Digestion ends in mid-intestine. Large intestine serves for water absorption and excrements removal. Food moves through intestines due to both vermicular motion and under press of food masses from fore intestine. Digestion quality depends on food amount [Tyshchenko,
1986]. Nutrient particles move through intestines for about 60 minutes. Algae are found to be the main food component for mosquito larvae from the Aedes genus [Gadzhieva, Shchaikhova, 2008]. For the Coquillettidia genus, adult larvae mainly feed on algae [Merritt et al., 1992].

The mosquito of $A$. communis is an optionally autogenic, monocyclic, early spring-summer, polytopic species. In the taiga zone, it normally inhabits moist coniferous forests, particularly spruce forests where its population is high and stable with female part in collection of $70 \%$ and more [Medvedev et al., 2010]. This species is autogenic, i.e. females of mosquitoes lay the first portion of eggs without blood sucking due to accumulation of nutrients at larval stage. The feature provides for an additive adaptation mechanism to decrease mortality at the first gonotrophic cycle and maintain population without feeders which is a usual situation for north mosquito populations [Nikolaeva, 1982].

By the literature data [Gozhenko, Titova, 1981; Merritt, Graid, 1987, Merritt et al., 1992; Gadzhieva, Shchaikhova, 2008], algae within food particles in mosquito larval intestines are normally studied when materials are fixed with alcohol, formaldehyde, or glycerin. Fixed samples often cannot provide for a precise identification of algal species composition. To identify algae to species, we need to follow the whole life cycle of alga which is possible only on isolation of strain into an algologically pure culture from live algae.

The purpose of the work is identification of species diversity and role of algae in food diet of Aedes communis (De Geer, 1776) larvae which is an abundant mosquito species in spruce forests of the taiga zone northwards of the Russian Plain.

\section{Materials and methods}

Adult larvae of the Aedes communis mosquito (in the suburbs of Syktyvkar N 61 $38^{\prime} 55^{\prime \prime}$ E 50 44'01") were collected in the third decade of May (22.05.2017). Larvae were sampled from snow melt water-body. Phenological observations of $A$. communis micro-population in temporal spring water-body in dwarf shrubgreen moss spruce forest date back to 2015. Larval nutrition of mosquitoes is a new monitoring aspect of the Culicidae family. For the second time, sampling was done next year (22.05.2018) under same conditions (Fig. 1) to ensure natural experiments on algal digestion by A. communis larvae. Excrements of larvae were studied in-vitro. Live well-fed larvae were put into a pure water drop for 30 minutes. Excrements were then analyzed using Nikon Eclipse80i microscope, amplification $\times 1000$.

The water-body for larval sampling is located in dwarf shrub-green moss spruce forest. Its size is $15 \times 5 \times 0.7 \mathrm{~m}$. Weather conditions at sampling time were similar between years. Spring 2017 was cool and long-lasting with air temperature $+10^{\circ} \mathrm{C}$, water temperature $+7{ }^{\circ} \mathrm{C}$, and neutral $(\mathrm{pH}=7.2)$ water medium 


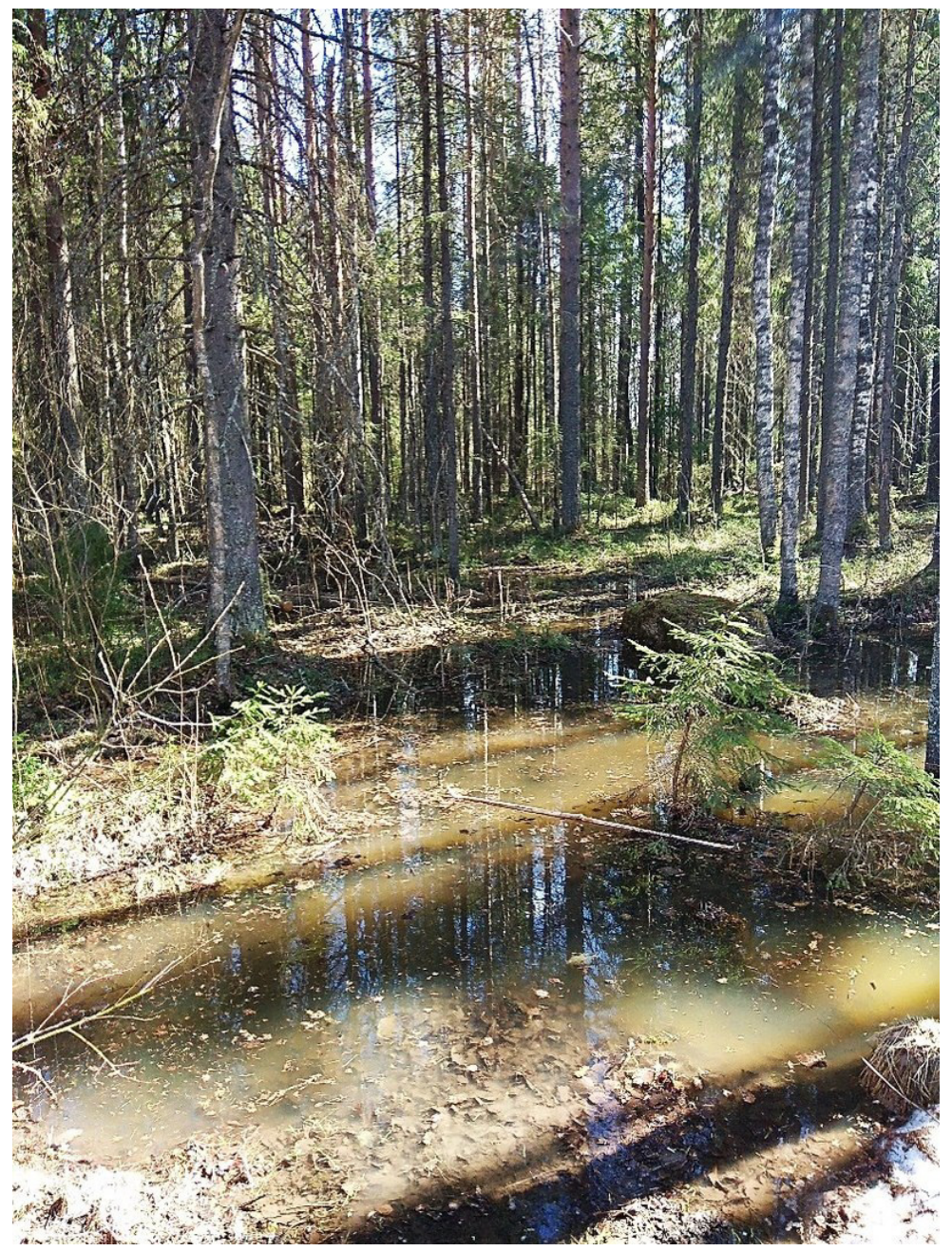

Fig. 1. The sampling site.

Рис. 1. Место сбора материала.

reaction. In 2018, mosquito adult (IV age class) larvae were sampled when water temperature was $+14{ }^{\circ} \mathrm{C}$, air temperature $+19^{\circ} \mathrm{C}$, water medium reaction - neutral $(\mathrm{pH}=7.1)$, and electrical conductivity $-102 \mu \mathrm{S}$. Larvae were collected with an enameled pan $0.13 x$ $0.18 \times 0.03 \mathrm{~m}$ and then put with pipette into $150-\mathrm{ml}$ tubes which contained water from water-body for $2 / 3$ of their volume. Adult (IV age class) larvae were identified in-vitro using $M B S$-10 binocular microscope. With help of ocular micrometer and binocular microscope, we measured width and length of head capsule (without collar) for 100 adult larvae and calculated head coefficient as a width-to-length ratio. When transporting, larvae were put into tubes with covers which allowed air to guarantee their viable state. To identify species composition of algae which are a principle food component of blood-sucking mosquitoes, intestines of 10 larvae were in-vitro opened with entomological needles in 30 minutes after they were taken from the water-body. Algal diversity was identified direct microscoping contents of mid-intestine and using enrichment- and mono-cultures. Mid-intestine con- tents were sown in $3 \mathrm{~N}$ BBM agarized nutrition medium. In mixed culture, algal colonies developed and were gradually observed, identified and isolated into an algologically pure culture. Algal species composition was determined in Nikon Eclipse 80i microscope, amplification $\times 1000$, with differential interference image contrast system. Micro-photos were done with $\mathrm{Ni}-$ kon Digital Sight Ds $-2 \mathrm{Mv}$ camera (Nikon, Japan). To identify algal species, we used indigenous Russian and foreign key books [Dedusenko-Shchegoleva, Gollerbakh, 1962; Ettl, 1978; Andreeva, 1998; Komarek, Anagnostidis, 1998; Komarek, 2013; Ettl, Gartner, 2014]. Some strains were isolated into an algologically pure culture and are now maintained in collection of live algal cultures at the Institute of Biology SYKOA (https://ib.komisc.ru/sykoa).

\section{Results}

Mouth of A. communis larvae is shaped for bottom scraping and filtering. Head index of adult larvae is $1.1 \pm 0.2$. Scraping is a dominating nutrition type. Up- 

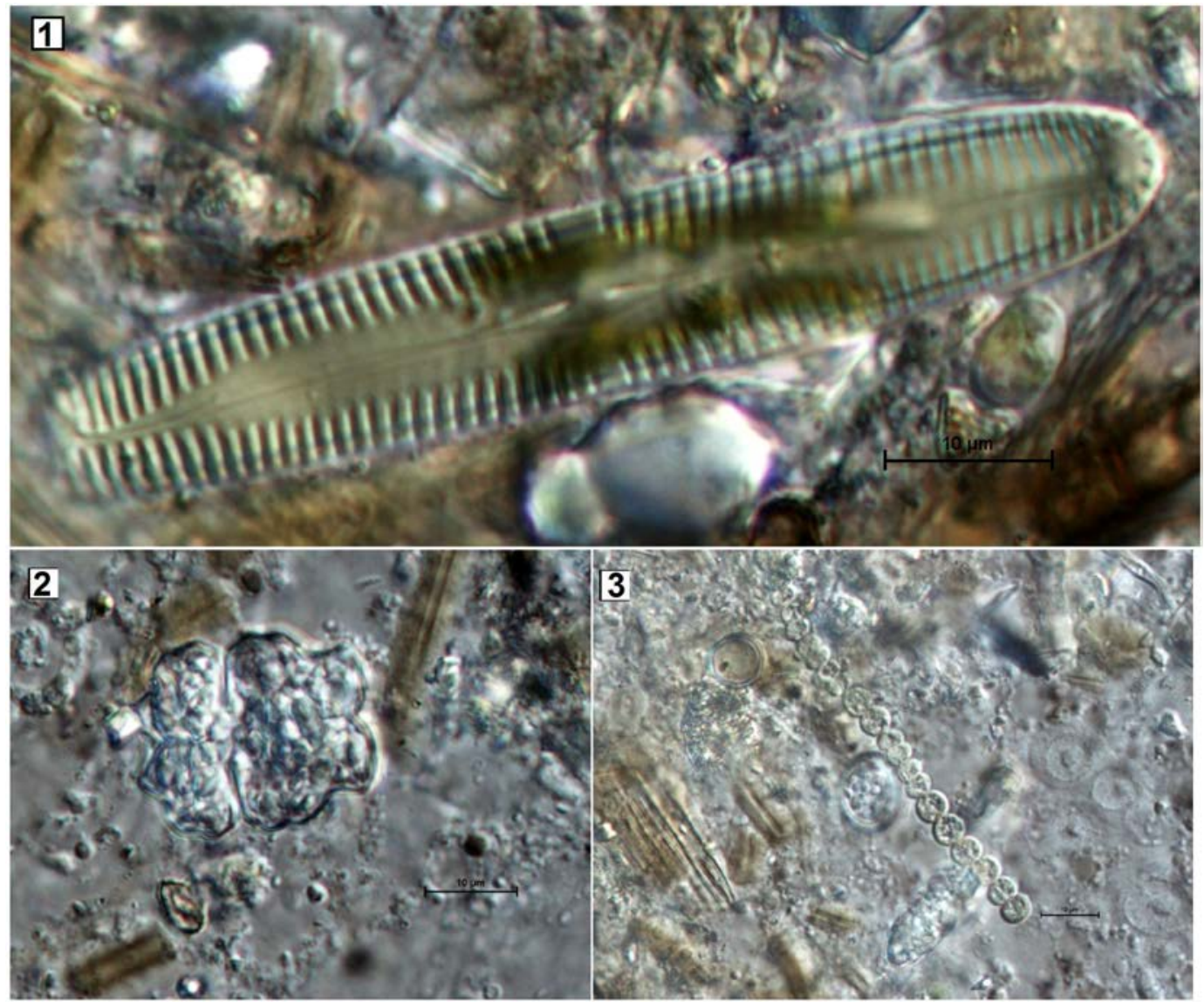

Fig. 2. Algae from larval intestines of the Aedes communis blood-sucking mosquitoes.

1 - Pinnularia sp.; 2 - Euastrum sp.; 3 - Anabaena sp.

Pис. 2. Водоросли, обнаруженные в кишечнике личинок кровососущих комаров Aedes communis.

per lip muscles are diagonal and jaw muscles are strong. Side blades of upper lip are wide-set. Mid-blade is short and wide. Hairs which form side blades are heterogeneous. There are inside and outside hairs. Inside hairs are short and thick and have rows of small teeth to scrape substrate. Upper jaws have a continuous ridge of long thorns and well-formed teeth along their upper side. Lower jaws have a poorly-developed feeler and tufts of hairs on tip. Tufts of hairs are different for different species [Gutsevich et al., 1970; Yasyukevich, 2003].

The nutrition diet of A. communis larvae consists of algae by $10-40 \%$. Totally, 12 algal species of five orders were identified. They are Cyanobacteria/Cyanoprokaryota (Chroococcus sp., Anabaena sp.), Ochrophyta (Botrydiopsis eriensis, Tribonema vulgare), Bacillariophyta (Pinnularia sp.), Chlorophyta (Bracteacoccus giganteus, Chloroidium saccharophilum, Microthamnion kuetzingianum, Pseudococcomyxa simplex, Schizochlamydella minutissima, Stichococcus bacillaris), and Streptophyta (Euastrum sp.). The majority of species were identified via both direct microscoping and cultivation in nutrition media. Unfortunately, we did not manage to cultivate cyanoprokaryotes, diatomic and streptophyte algae. So they are iden- tified by genus. The possible causes of this failure may be destruction of algal membranes in mosquito intestines and intensive digestion. Also, some part of diatomic algae may be initially empty cells.

Here, there is a short list of algal taxa taken from $A$. communis intestines.

1. Chroococcus sp. is a colonial cyanoprokaryote with a coccoid thallome organization. Cell size is 4 $\mu \mathrm{m}$. Colonies are mucous with globular or semi-globular cells. It can accumulate glycogen as a nutrition reserve. The species is single in larval intestines.

2. Pinnularia sp. (Fig. 2, 1) belongs to one-cell diatomic algae with a coccoid thallome organization. Cells are $15 \mu \mathrm{m}$ wide and $70 \mu \mathrm{m}$ long. Membrane is a siliceous shell which consists of two halves. Beginning with girdle, shell is a rectangle and leaflets are ellipses. Diatomic algae accumulate volutin and oil drops. It is highly abundant in intestines of all studied larvae.

3. Euastrum sp. (Fig. 2, 2) is a one-cell desmid with a coccoid thallome organization. Cells are $26 \mu \mathrm{m}$ long and $21 \mu \mathrm{m}$ wide. They are single, angular and are divided into two semi-cells in the centre. Membrane is smooth. The reserves are starch. It is singly-met in intestines of the studied larvae. 

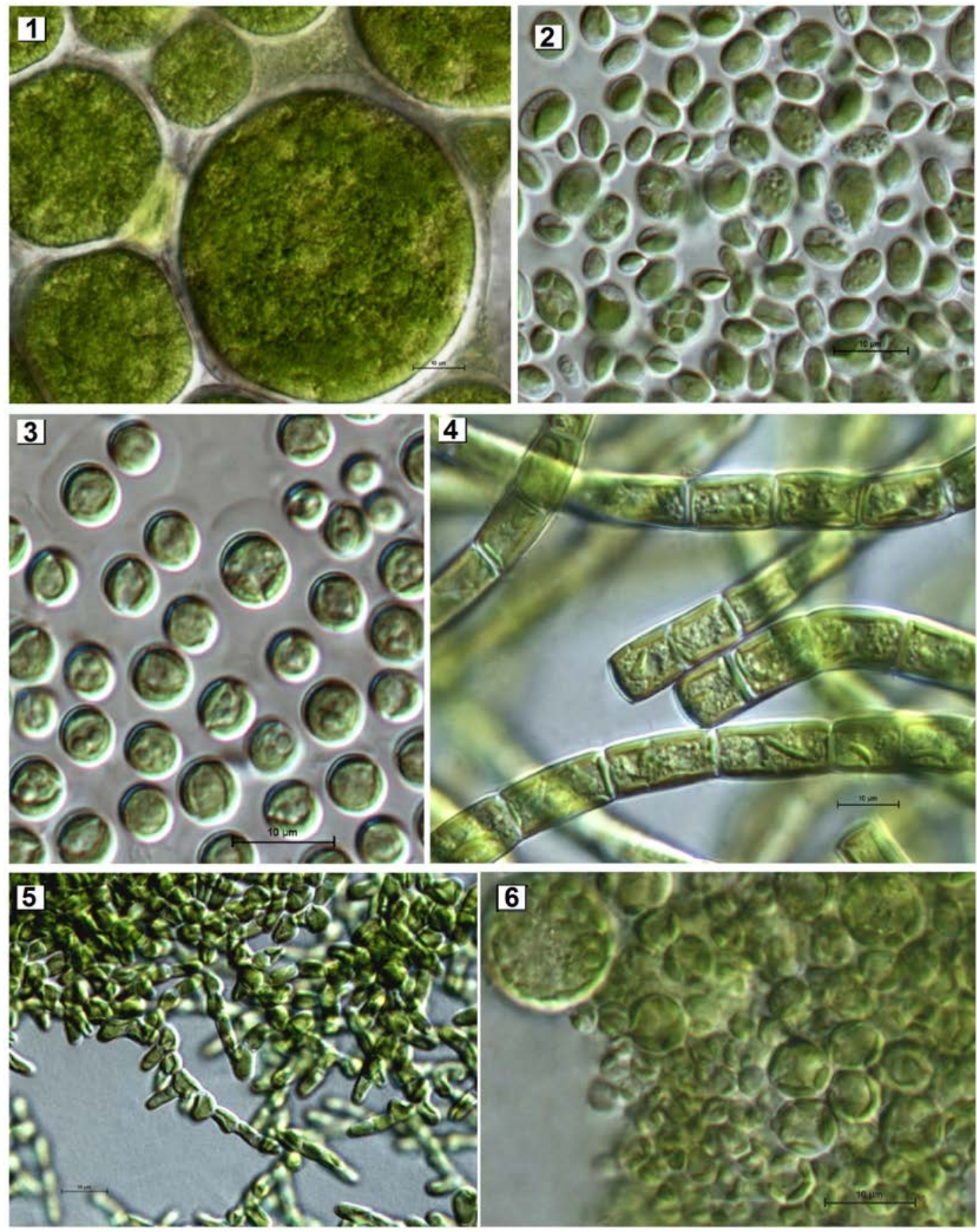

Fig. 3. Micro-photos of live algal strains which are a food component for larvae of Aedes communis blood-sucking mosquitoes.

1 - Bracteacoccus giganteus; 2 - Chloroidium saccharophilum; 3 - Schizochlamydella minutissima; 4 - Tribonema vulgare; 5 Microthamnion kuetzingianum; 6 - Botrydiopsis eriensis.

Рис. 3. Микрофотографии живых штаммов водорослей, составляющих пищевой компонент личинок кровососущих комаров Aedes communis.

4. Anabaena sp. (Fig. 2, 3) is a multicellular cyanoprokaryote with a filamentous thallome organization. Cells are rounded, $5 \mu \mathrm{m}$ in diameter. It accumulates glycogen and is highly abundant in intestines of the majority of studied larvae.

5. Bracteacoccus giganteus H.W. Bischoff et H.C. Bold (Fig. 3,1 ) is a one-cell green alga with a coccoid thallome organization. Cell size is 6-107 $\mu \mathrm{m}$. Cells are globular with a smooth membrane. With age, membrane becomes up to $7.5 \mu \mathrm{m}$ thick. The species accumulates starch and oil drops. It is highly abundant in intestines of all studied larvae.

6. Chloroidium saccharophilum (W. Krüger) Darienko, Gustavs, Mudimu, Menendez, Schumann, Karsten, Friedl et Proschold (Fig. 3, 2) is a one-cell green alga with a coccoid thallome organization. Cells 
are 4.4-12.2 $\mu \mathrm{m}$ long and 2.2-11.1 $\mu \mathrm{m}$ wide. Cells are ellipses, broad ellipses, egg- or pear-shaped with a relatively thick membrane. The species accumulates colorless oil drops. It is poorly abundant in intestines of the majority of studied larvae.

7. Schizochlamydella minutissima Broady (Fig. 3, 3 ) belongs to colonial green algae with a coccoid thallome organization. Cell size is $2-7 \mu \mathrm{m}$ in diameter. Cells are globular with individual mucus of $2.5 \mu \mathrm{m}$. Reserves are starch and oil drops. It is poorly abundant in intestines of the majority of studied larvae.

8. Tribonema vulgare Pascher (Fig. 3, 4) is a multicellular yellow-green alga with a filamentous thallome organization. Cells are $6-8 \mu \mathrm{m}$ wide and $48 \mu \mathrm{m}$ long. They are cylindrical and become cask-shaped with age. Membrane becomes thick with age. Nutrition reserves are chrysolaminarin and oil drops. It is highly abundant in intestines of the majority of studied larvae.

9. Microthamnion kuetzingianum Nägeli ex Kütz. (Fig. 3,5) is a multicellular green alga with a filamentous thallome organization. Cells are 3-5 $\mu \mathrm{m}$ wide and $20 \mu \mathrm{m}$ long. Cells are columnar, except for basal cells, with a thin membrane. The assimilation product is an oil-like substance. It is highly abundant in intestines of the majority of the studied larvae.

10. Botrydiopsis eriensis J.W. Snow (Fig. 3, 6) is a yellow-green alga and belongs to one-cell varieties with a cocoid thallome organization. Cell size is 6.3$18 \mu \mathrm{m}$ in diameter. Cells are globular; some of them contain poor mucus. Membrane is thin and becomes thick with age. As reserves, it accumulates oil drops and chrysolaminarin. It is highly abundant in intestines of the majority of studied larvae.

11. Pseudococcomyxa simplex (Mainx) Fott belongs to one-cell green algae with a coccoid thallome organization. Cells are $10 \mu \mathrm{m}$ long and $3 \mu \mathrm{m}$ wide. Cells are ellipsoid-shaped or elongated with one end being wide. The other narrow end sometimes forms a mucous pad. The reserves are colorless oil drops. It is highly abundant in intestines of all studied larvae.

12. Stichococcus bacillaris Nägeli belongs to multicellular green algae with filamentous thallomes. Cells are columnar, straight with rounded edges. They are 8 (12) $\mu \mathrm{m}$ long and $3 \mu \mathrm{m}$ wide. Membrane is thin without mucus. The assimilation product is starch and an oil-like substance. It is highly abundant in intestines of all studied larvae.

\section{Discussion}

Algae are a permanent food component for larvae of Aedes communis blood-sucking mosquitoes. There is no one algae which larvae would prefer to the others. Our data agree with the other authors' results [Yasyukevich, 2003; Gadzhieva, Shaikhova, 2008; et al.]. Food diet of mosquito larvae consists of diverse green algae which dominate in coniferous phytocenoses of the middle taiga zone reasoning from such parameters as composition and abundance [Novakovskaya,
Patova, 2011]. The majority of algal species are a onecell variety. Coccoid organization of morphological structure is popular and includes species with a thick membrane and being immobile at vegetative stage. Cell size varies within the diapason of 9-76 $\mu \mathrm{m}$.

Analyzing larval excrements, diatomic algae do not get destructed in A. communis intestines. Mosquitoes partly do not digest Ochrophyta and green algae which are situated in the middle of food bolus and get out of the organism intact. Like bottom particles larvae eventually swallow diatomic and green algae. Siliceous frustules of diatoms and cellulose membranes of green algae possibly serve to rub and mill food in intestines. The mid-intestinal motility is known to be absent in organism of mosquito larvae. Food masses move under press of newly-swallowed portions [Beklemishev, 1944; Merritt, Graid 1987].

Larvae of A. communis feed on algae which accumulate a broad spectrum of nutrition elements required for successful growth and molting, as well as for the process of autogeny. Diatoms and Ochrophyta algae are sources of lipids, volutin, chrysolaminarin, and fucoxanthin. Green algae contain starch and special substances which compensate energy expenses of mosquito larvae when they breathe, move or molt. Cyanoprokaryotes include glycogen and glutamic acid which participate in metabolism processes. Glycogen is also used for chitin formation when molting [Chauvin, 1953].

Several algal strains isolated from intestines of mosquito larvae are maintained in algal collection at the Institute of Biology. In future, they can be possibly used to manage number of this mosquito species in natural conditions.

\section{Acknowledgements}

The work was financially supported by the state theme 'The taxonomy, distribution, and spatial organization of fauna, and ground and water animals populations in taiga and tundra ecosystems of the European North-East of Russia' (No. AAAA-A17117112850235-2) and partly by the theme "The structural-functional organization of plant communities, diversity of flora, lichen-, and mycobiota in the southern part of the Yugyd Va National Park" (No. AAAAA16-116021010241-9). The authors thank E.V. Kyzyurova for evaluating $\mathrm{pH}$ in water-body.

\section{References}

Andreeva V.M. 1998. [Soil and aerophilous green algae (Chlorophyta: Tetrasporales, Chlorococcales, Chlorosarcinales).] SaintPetersburg: Nauka Publ. 352 pp. [In Russian]

Beklemishev V.N. 1944. [Ecology of the Anopheles maculipennis Mg. malarial mosquito.] Moscow: Medgiz. 229 pp. [In Russian]

Chauvin R. 1953. [Physiology of Insects.] Moscow: Izdatel'stvo Inostrannoy Literatury. 495 pp. [In Russian]

Dedusenko-Shchegoleva N.T., Gollerbakh M.M. 1962. [Yellowgreen algae] // Opredelitel' presnovodnykh vodoroslei SSSR. Moscow- Leningrad. Is.5. 271 pp. [In Russian]

Ettl H. 1978. Xanthophyceae // Süßwasserflora von Mitteleuropa. I. Teil. Bd.3. Stuttgart. $530 \mathrm{~S}$. 
Ettl H., Gartner G. 2014. Syllabus der Boden-, Luft-und Flechtenalgen. 2. Auflage. $773 \mathrm{~S}$.

Gadzhieva S.S., Shaikhova A.A. 2008. [Towards larval nutrition of blood-sucking mosquitoes (Culicidae) in South Dagestan] // Yugh Rossii: ekologiya, razvitie. No.2. P.71-73 [in Russian, with English summary].

Gozhenko V.A., Titova L.İ. 1981. [Towards nutrition of bloodsucking mosquitoes (Culicidae)] // Parasitologiya. Vol.15. No.3. P.265-269 [in Russian, with English summary].

Gutsevich A.V., Monchadsky A.S., Shtakelberg A.A. 1970. [Mosquitoes of the Culicidae family] // Fauna SSSR. Dvukrylye. Vol.3. Is.4. Leningrad: Nauka Publ. 384 pp. [In Russian]

Komarek J. 2013. Cyanoprokaryota III: Nostocales, Stigonematales // Sußwasserflora von Mitteleuropa. Berlin. Bd. 19/3. 1130 S.

Komarek J., Anagnostidis K. 1998. Cyanoprokaryota I. Teil: Chroococcales // Sußwasserflora von Mitteleuropa. Heidelberg, Berlin. Bd. 19/1. $548 \mathrm{~S}$.

Lyapunov A.N., Panyukova E.V. 2010. [About the role of imago blood-sucking mosquitoes (Diptera, Culicidae) for nutrition of chiropterans (Chiroptera, Vespertilionidae) in the Kirov region] // Teoreticheskaya i prikladnaya ekologiya. No.4. P.8793 [in Russian, with English summary].

Merritt R.W. 1987. Do different instars of Aedes triseriatus feed on particles of the some size? // J. Am. Mosquito Control Assoc. Vol.3. No.1. P.94-96.

Merritt R.W., Graid D.A. 1987. Larval mosquito (Diptera, Culicidae) feeding mechanisms: mucosubstance production for captur of fine particles // J. Med. Ent. Vol.24. No.3. P.275-278.

Merritt R.W., Dadd R.H., Walker E.D. 1992. Feeding behavior, natural food, and nutritional relationships of larval mosquitoes // Annu. Rev. Entomol. Vol.37. P.349-374.
Medvedev S.G., Aibulatov S.V., Panyukova E.V. 2010. [Ecological features and distribution of Aedes communis (De Geer, 1776) in the North-East of the European part of Russia] // Parasitologiya. Vol.44. No.5. P.441-460 [in Russian, with English summary].

Narchuk E.P. 2003. [Key Book for Families of Dipteral Insects in Russia and neighboring states] // Trudy Zoologicheskogo Instituta RAN. Vol.294. Saint-Petersburg. 250 pp. [In Russian]

Nikolaeva N.V. 1982. [Autogeny in populations of blood-sucking mosquitoes in South Yamal (Culicidae)] // Parasitologiya. Vol.16. No.4. P.300-305 [in Russian, with English summary].

Novakovskaya I.V., Patova E.N. 2011 [Soil algae of spruce forests and how they change in conditions of aerotechnogenic pollution] Syktyvkar. 128 pp. [In Russian]

Tarasov V.V. 1996. [Medical Entomology.] Moscow: MGU. 352 pp. [In Russian]

Tyshchenko V.P. 1986. [Physiology of Insects: Textbook for Biology Students.] Moscow: Vysshaya Shkola. 303 pp. [In Russian]

Yasyukevich V.V. 2003. [Towards larval nutrition of blood-sucking mosquitoes (Diptera, Culicidae)] // Entomologicheskoe Obozrenie. Vol.82. No.1. P.63-70 [in Russian, with English summary].

Yurchenko Yu.A., Belevich O.E. 2016. [The similarity degree among results of quantitative determination of blood-sucking mosquitoes (Diptera, Culicidae) breeding using the hydrobiological method and cone-shaped traps] // Sibirskiy ekologicheskiy zhurnal. J. No.4. P.533-542 [in Russian, with English summary].

https://ib.komisc.ru/sykoa Collection of microalgae strains in the Institute of Biology of Komi Scientific Centre (accessed on November 26th, 2018) 